\title{
Acute necrotizing retinitis in a patient receiving immunosuppressive therapy
}

\author{
RIGHARD PORTER \\ University Department of Ophthalmology, Royal Victoria Infirmary, Newcastle-upon-Tyne
}

Patients with impaired immunological defence mechanisms due to malignant invasive conditions such as the leukaemias and their associated cytotoxic drug therapy, or to the administration of immunosuppressive drugs, are particularly prone to infection with organisms usually thought of as benign under normal conditions. In particular the incidence of cytomegalic inclusion disease is increasing both in children (Cangir and Sullivan, 1966) and adults (Wong and Warner, 1962; Smith, 1964; Hedley-Whyte and Craighead, 1965) under these conditions, and in a very small minority of these patients ocular involvement has been reported (Burns, 1959; Dvorak-Theobald, 1959; Smith, 1964; Ashton and Cunha-Vaz, I966; Wallow, 1969; de Venecia, Zu Rhein, Pratt, and Kisken, I97 I).

This is a report of a patient who developed a bilateral necrotizing retinitis while receiving immunosuppressive therapy after a renal transplant operation.

\section{Case report}

A 27-year-man was first seen in March, 1970, as part of an ocular survey of patients with renal transplants. A year previously he had received a transplanted kidney from his brother a fter his own renal failure. The immediate postoperative period had been stormy, and of possible significance at that time was an attack of acute parotitis which had resolved with antibiotic therapy. The postoperative rejection phenomenon had continued to prove difficult to control and cyclophosphamide had been added to the more usual immunosuppressive therapy of prednisone and azathioprine. This regime had had to be continued in order to maintain a reasonable renal function and when he was seen in the ophthalmic department one year later he was still receiving azathioprine $150 \mathrm{mg}$. per day, prednisone $50 \mathrm{mg}$. four times a day, and cyclophosphamide $30 \mathrm{mg}$. per day. He complained of reduced vision in the right eye dating from the time of uncontrolled hypertension 2 years previously.

First ocular examination March 16,1970

The vision in his right eye was reduced to 6/6o. The disc was flat with signs of secondary optic atrophy. There was a localized flat pigmentary lesion at the macula, but the rest of the fundus was normal apart from some small areas of chorio-retinal degeneration at the extreme periphery. The left eye, with a visual acuity of $6 / 6$ and $N_{4.5}$ uncorrected, was normal. The reduced acuity in the right eye was attributed to a previous hypertensive retinopathy.

He remained well over the next year apart from developing a painful left knee with a moderate effusion. This was subsequently found to be due to an area of osteochondritis dessicans secondary to an area of ischaemic bone necrosis.

Second ocular examination February 15,197 I

On this occasion he was complaining of a painless reduction in the already poor vision of the right eye, and on examination this was found to be reduced to hand movements. There were signs of an anterior uveitis together with a hazy vitreous particularly in the region of the disc which was atrophic and flat but with blurred edges (Fig. I). The original macular lesion was still present but apart from a small area of oedematous retina around the macula, the rest of the fundus was disorganized with 
destruction of the retina and superficial choroid exposing the deeper choroidal vessels. Despite this degree of retinal destruction there was remarkably little reactive hyperplasia of the pigmentary epithelium and the characteristic clumping was notably absent (Fig. 2). The left eye remained unaffected with an uncorrected vision of $6 / 6$.

(I)

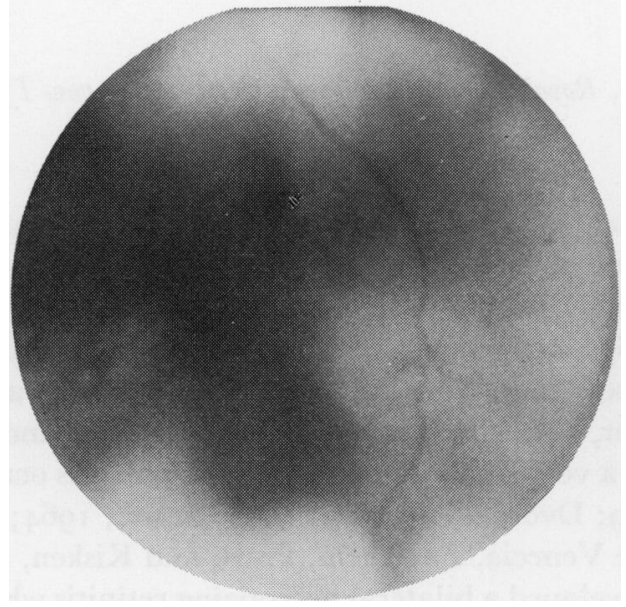

(2)

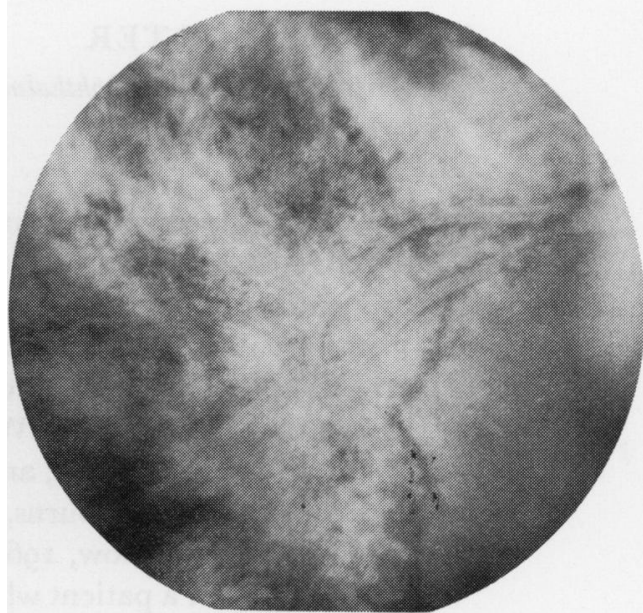

FIG. I Right atrophic disc with old pigmented macular lesion

FIG. 2 Right fundus, showing destruction of retina and obliteration of retinal arteries after inflammatory reaction had subsided

Seven days later the acuity in the left eye had dropped to 6/12. There was a moderate anterior uveitis but, as in the right eye, the main inflammatory reaction was at the posterior pole of the eye with a cloudy vitreous, and at the extreme periphery of the retina completely encircling the eye was a circumferential strip of acute exudative retinitis with occlusion of the vessels and superimposed retinal haemorrhages (Fig. 3). In four days this rapidly extended across the retina to reach the disc (Fig. 4) and the acuity fell to hand movements. The inflammation was predominantly an
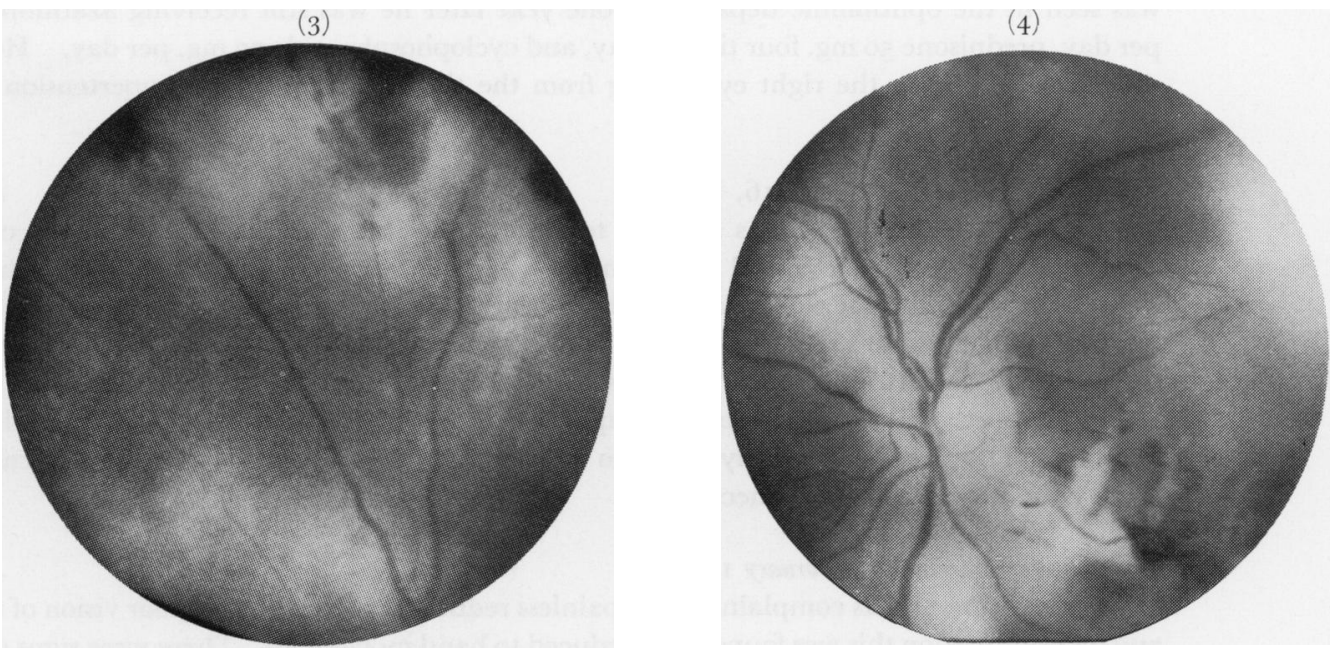

FIG. 3 Early stages of retinitis in periphery of left eye

FIG. 4 Retinitis reaching left disc with areas of retinal haemorrhage and numerous small thrombotic vein occlusions 
exudative retinitis associated with a necrotizing vasculitis typified by thrombotic occlusion of the veins, obliteration of the arteries, and perivascular sheathing of both types of vessels, together with extensive retinal haemorrhages. At this stage the fundus presented a distinctive picture, the normal red background being replaced by the straw colour of the retinal exudates and oedema from which the thrombosed vessels and the retinal haemorrhages stood out in marked relief (Fig. 5).

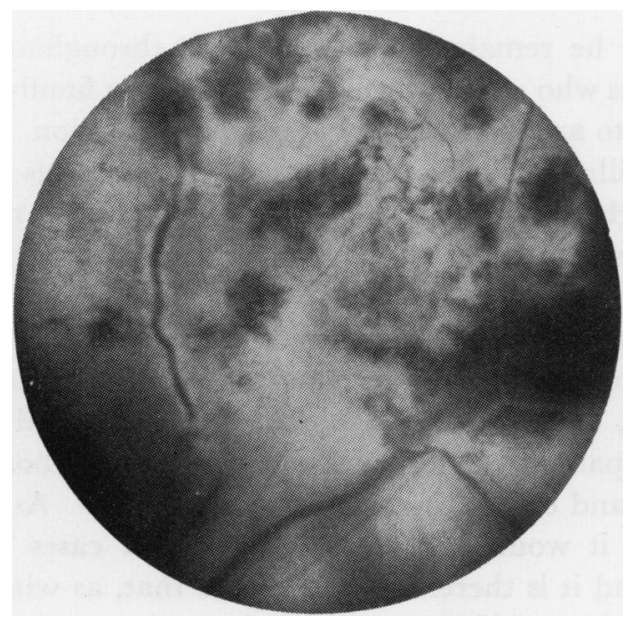

FIG. 5 A picture eventually typical of the whole of the fundus, showing obliteration and sheathing of the arteries and thrombotic occlusions of the veins. The dark areas are retinal haemorrhages

One month later most of the inflammatory reaction had subsided leaving the left eye in a similar state to the right with optic atrophy and destruction of most of the retina but again with very little pigmentary reaction (Fig. 2). The final visual acuity was $3 / 60$ right and $3 / 36$ left and 6 months later this had not improved.

\section{Laboratory Investigations}

Hb 108 g. per cent.

W.B.C. I2, 100 per cu. $\mathrm{mm}$.

Platelets 340,000 per cu mm.

Creatinine clearance $4 \mathrm{I} \cdot 2 \mathrm{ml}$./min.

Blood urea $45 \mathrm{mg}$. per cent.

Blood creatinine $2 \cdot 8 \mathrm{mg}$. per cent.

Chest $x$ ray nothing abnormal
Electrolytes (m Eq/1.)

$\mathrm{Na}^{+}{ }_{140}, \mathrm{~K}+3 \cdot 5$,

$\mathrm{Cl}^{-}$104, Bicarb 22.

Serum protein $7 \cdot 4 \mathrm{mg}$. per cent.

Serum Ca $8 \cdot 3 \mathrm{mg}$. per cent.

Serum phosphate $2 \cdot 6 \mathrm{mg}$. per cent.

Alkaline phosphatase 56 K.A. units

Complement-fixation antibodies to cytomegalovirus present in dilutions $>1 / 640$.

Toxoplasmosis dye test $<\mathrm{I} / 8$.

No antibodies were detected to herpes simplex virus, adenovirus, or mumps virus.

The following serological tests were negative: Wassermann reaction; Kahn test; Reiter protein complement-fixation test; gonococcal complement-fixation test; modified Waaler-Rose, antinuclear factor.

\section{Comment}

Although it is known that many fit adults possess antibodies to cytomegalovirus (Rowe, Hartley, Waterman, Turner, and Huebner, 1956; Embil, Haldane, McKenzie, and van Rooyen, 1970), the extremely high titre present in this patient, who is receiving therapy specifically designed to reduce antibody formation, would seem to confirm that an active cytomegalic inclusion disease is present. That the retinitis is caused by this virus is further confirmed by the close similarities between the clinical appearance in this 
case and that in the recently reported case of a histologically diagnosed cytomegalic inclusion retinitis (de Venecia and others, 1971).

Cytomegalic inclusion retinitis is a rare ocular complication and has only been reported in four cases in adults (Smith, I964; Ashton and Cunha-Vaz, 1966; Wallow, 1970; de Venecia and others, I97 I) and only recently in the last two reports has the clinical picture been described.

The patient is of interest in that he remained remarkably fit throughout in contradistinction to the other reported cases who were so debilitated that they finally succumbed either to the original malignancy or to an overwhelming secondary infection. At no time did he show any sign of a systemic illness and he would have continued his employment in heavy industry had his loss of sight not prevented it. The fulminating nature of the retinitis was most marked and in this respect it appears to have been worse than the other reported cases.

It has previously been found in systemic cytomegalic inclusion disease that the cytomegalovirus was much more virulent in patients receiving both cytotoxic and immunosuppressive drugs (Reinhard, Good, and Martin, 1950), and the combined use of these drugs, necessitated as it was in this patient by the persistent rejection phenomenon, may $\cong$ have been responsible for the rapid and extensive nature of the retinitis. As the number of organ transplant cases increases it would seem likely that more cases with similar ocular complications will develop and it is therefore unfortunate that, as with most virus infections, there is no effective treatment. However, it has been shown in experimental studies that mice infected with cytomegalovirus had much more virulent systemic infections when treated at the same time with steroids (Henson, Smith, Gehrke, and Neapolitan, 1967), which suggests that it may be possible to exert some control over the virus if the steroids can be stopped or reduced as much as possible.

\section{Summary}

A case of acute necrotizing retinitis is described in a patient receiving immunosuppressive therapy after a renal transplant operation. It is suggested that cytomegalovirus is the most likely causative organism.

I should like to thank Dr. R. Udall, under whose care the patient was admitted to hospital, for permission to publish this report.

\section{References}

ASHTon, N., and cunha-vaz, J. G. (1966) Arch.port. Oftal., 18, Suppl. 39 (Ophthal. Lit., 1966, 20, 475) BURns, R. P. (1959) A.M.A. Arch. Ophthal., 6r, 376

Cangir, A., and sullivan, M. P. (1966) F. Amer. med. Ass., 195, 6 I 6 DE venecia, G., zU RHEIN, M., PRATt, M. v., and kISken, w. (197I) Arch. Ophthal. (Chicago), 86, 44 J̃ DVORAK-THEOBald, G. (1959) Amer. 7. Ophthal., 47, no. 5, pt. II, p. 52 embil, J. A., haldane, e. v., Mckenzie, R. A. E., and van rooyen, c. E. (ig69) Canad. med. Ass. J., ror, 730 hedley-Whyte, E. T., and CRAighead, J. E. (1965) New Engl. J. Med., 272, 473 henson, D., SMith, R. D., Gehrke, J., and neapolitan, c. (1967) Amer. J. Path., 51, ioo I reinhard, E. H., good, J. T., and martin, e. (i950) J. Amer. med. Ass., 142, 383 Rowe, w. P., hartley, J. W., WAterman, s., TURner, H. G., and huebner, R. J. (1956) Proc. Soc. exp. Biol. (N.Y.), 92, 418 SMrTH, м. Е. (1964) Arch. Ophthal. (Chicago), 72, 44 WALlow, r. (1969) Ber. dtsch. ophthal. Ges., 70, 55 Wong, T. W., and Warner, N. E. (1962) Arch. Path., 74, 403 